\title{
Structure, value and context of tembang pisaan culture in runjung agung district
}

\author{
Yezi Yuliya $^{1}$, Missriani $^{2}$, Yessi Fitriani $^{3}$ \\ ${ }^{1}$ SMA Negeri 1 Runjung Agun \\ ${ }^{2}$ Universitas PGRI Palembang
}

\begin{tabular}{ll} 
Article Info & ABSTRACT \\
\cline { 2 - 3 } Article history: & $\begin{array}{l}\text { This study aims to identify and describe the structure, values, and cultural } \\
\text { context of the Tembang Pisaan oral literature. The research method used is } \\
\text { descriptive qualitative research method because literature is a form of creative } \\
\text { Received Jul } 12^{\text {th }}, 2021\end{array}$ \\
$\begin{array}{l}\text { werk that is constantly changing. Data collection techniques used; observation, } \\
\text { interviews, documentation and recording techniques. The data analysis } \\
\text { Accepted Aug } 30^{\text {th }}, 2021\end{array}$ & $\begin{array}{l}\text { technique used is; domain analysis, taxonomic analysis, component analysis, } \\
\text { and culture theme analysis. The result of this research is that the oral literature } \\
\text { of Tembang Pisaan has a physical and mental structure. Meanwhile, the value } \\
\text { analysis in this study is cultural values and religious values, namely those } \\
\text { Keyword: }\end{array}$ \\
concerning the relationship between man and God, human relationship with \\
society, and human relationship with himself. The cultural context is in the \\
form of its application in society, because the pisaan song is rich in customs, \\
Cultural context \\
Tembang pisaan.
\end{tabular}

(C) 2021 The Authors. Published by IICET.

cC)(ㄱ) This is an open access article under the CC BY-NC-SA license BY NC SA (https://creativecommons.org/licenses/by-nc-sa/4.0

\section{Corresponding Author:}

Yezi Yuliya

SMA Negeri 1 Runjung Agun

Email: yuliayez211@gmail.com

\section{Introduction}

Culture is a sediment from human activities and works. It is no longer interpreted solely as a manifestation of virtuous human life such as religion, art, philosophy and so on. Today culture is defined as the manifestation of the life of each person and group in a broad sense. In Law No. 5 of 2017 concerning the advancement of culture, it is stated that regional cultural diversity is a wealth and national identity which is indispensable to advancing Indonesian national culture amid the dynamics of world development.

Literature as a branch of art, both of which are integral elements of culture, is getting old. The presence of literature almost coincides with the existence of humans, because literature is created and enjoyed by humans and has become part of the experience of human life. In terms of its creation regarding people's lives in a certain period of time [1].

The researcher's consideration was to choose Tembang Pisaan as research material because Tembang Pisaan is a cultural result of the Daya community which contains cultural values and is still used until now, but its use is only limited to people who are old and appointed. Researchers hope that with this research, the younger generation will have the desire to study tembang pisaan as a cultural heritage from their ancestors. 
[2] old literature or regional literature that is not preserved will become extinct, because most of it is still stored in the minds of people who are old. Likewise, the existence of oral literature on the Tembang Pisaan which has not been recorded, and is only controlled by people who are old or appointed only, for example, traditional leaders, village elders and so on. This regional literature will become extinct if there is no directed maintenance, such as being used as subjects in schools or distributed as reading books.

One very important source of regional cultural information is regional literature in oral form. Oral literature is a cultural archive of various regional cultural data, because in it there are various sciences, teachings, customs which have many noble values of the supporting community.

\section{Method}

It is said to be descriptive because in this study, it describes the data based on facts objectively according to the data found [3]. This research is a qualitative descriptive research type because this research produces descriptions in the form of words of structure, values and cultural context of the pisaan song. Descriptive method is a research method that contains an explanation or description of something [4].

\section{Results and Discussions}

This research begins with data collection by conducting interviews with resource persons, namely Mr. Busnan Abubakar as the customary leader of Runjung Agung Subdistrict, then the next step is by listening and witnessing firsthand the implementation of Tembang Pisaan in giving custom titles at the wedding ceremony of the Daya community, Runjung Agung District, then by interpreting and finding the meaning contained in the oral literature of the Tembang Pisaan. inner structure, values, and cultural context contained in the pisaan song. The physical structure of the Tembang Pisaan namely:

\section{Diction}

Diction is the choice of words made by a poet in his poetry. [5] diction is the choice of words used by poets in constructing meaning in a poem. In the pisaan song, there is the use of diction which supports the meaning and aesthetic value. As contained in the following pisaan song:
Jak sai mitdi qua
(from one to two)
Jukna caqa bubilang
(that's how it counts)
Numpang ngeqangkai bunga
(hitching a flower arrangement)
Simakkung Niku Kembang
(before you get proposed by someone)

In the above pisaan song, the poet chooses to use very subtle diction, as found in the word hitching a flower with simakkung niku kembang, which means that if you may want to intend to approach if the girl has no partner.

\section{Image}

An image or also called an image is a word arrangement that can create an atmosphere, feeling or other form of imagination in the form of the imagination of various human senses such as hearing, sight and feeling. [6] Consider the following examples of pisaan songs!
Niku Muli Jak Palembang
(you are a girl from Palembang)
Judu meqanai jak tribe Daya
(matched with men from the Daya tribe)
Niku sambut hikam baka lalang
(we welcome you happily) 


\section{Juak ni hikam lain dehaqa \\ (the unspeakable happy feelings we felt)}

The image in the example of the pisaan song above, depicted in the sentence Niku welcomes hikam baka lalang, juakni hikam another dehaqa means the bride is greeted with feelings of happiness, joy and with all the joy of the heart.

\section{Concrete Words}

[5] a concrete word is a word that can evoke the image or image of the reader. [8] to generate an image, words must be concrete. This means that they can suggest a holistic meaning. As well as the concretized word reading is closely related to the use of figures or symbols.
Ngakuk Kabingni Maqnu
(take a large rattan stem)
Di Ataq Bukit Saqdang
(in the saqdang hill area)
Amon labuhan tantu
(if the berth is certain)
Lanting haga kukaqang
(I will row the raft)

Amon labuhan tantu, lanting haga kukaqang, have the meaning that if in the girl's heart there is still a place to anchor hope, then my heart and hope will tie in to build togetherness with the girl.

\section{Majas}

Majas is a language style that is used to generate and create images using comparative, figurative, symbolic and so on. [9], figure of speech is the use of language by enlarging or increasing the effect and causing certain connotations with figurative language that causes many meanings.

Pujadini kuti ayuk Rohana

(the one who brings you closer is ayuk Rohana)

He became a pearl star

(she became a pearl star)

Tungkop kdo sumbung di tehna

(love him with all his body and soul)

Simakkungni tehna tutup usia

(before he died)

\section{Verification}

According to [5] verification is things related to rhyme, rhythm and meter. Almost all the verses in the pisaan song use intermittent rhyme rhymes, namely rhymes $a-b-a-b$ or a-a-a-a.

Inymu iny bunga

(inymu is iny flower)

Gelaqni adat suku daya

(name of the customary title in the Daya tribe)

Niku mantuni hikam siteha

(you are our oldest son-in-law)

Dang mak hlau-hlau pribahasa 


\section{Tipoggrafi}

[5] Typography or facial arrangement is a form of poetry such as pages filled with words, left-right edges, and line arrangements, to lines of poetry that do not always start with capital letters and end with periods.

Selamat datang diundangan

(welcome to the invited party)

Ucapan yang pertama

(as the first greeting)

Amon pandai lancaq bhan

(if you have time to play at home)

Hayuni kuti dija

(when you are here)

\section{Theme}

Themes are the main ideas that establish the structure of the content. The theme concerns all feelings in human life, in the form of problems of humanity, power, affection, jealousy, and so on. [5]. Meanwhile, a theme is something that becomes the mind of the author and is the basis for the poetry created by the poet [7].

Kapan kok tungguk behan

(when you get home)

Gancang haga kekaqian kan

(must quickly prepare the dish)

Kung mudah-mudah kekaqian kan

(haven't prepared the dish quickly)

Gilok-gilok haga butangan

(angry about beating his wife)

Taste

According to Dibia (2018: 117) [8] taste is a factor that influences poetry creation. The mood of the poet's feelings is also expressed and must be lived out by the reader.

Hikam at qalik nyapa

(we can't greet one by one)

Gusi pehun siqatong sa

(Ladies and gentlemen who were present)

Qasa lega hik bangga

(relieved and proud)

Qam pandai puawoq dija

(we can meet here)

Tone

[5] Tone is a poet's attitude towards the reader. Tone also relates to theme and taste. Poets can convey themes and tones patronizing, and dictating.

Pudak Halok pandai bela

(a beautiful / handsome face can age)

Ammon kok uni dikanik waktu

(if it's eaten by age) 

At lain jak helau tegoq teqida
(by having a polite manner and manner)
Hna si pandai ngusung niku
(that's what can lead you to goodness)

\section{Mandate}

[9] Mandate is the message the poet wants to convey to the reader through the poem. Like the mandate in the following poetry of the pisaan song, so that you are more active in your work and do not often tell the ugliness of other people for your own family.

Dang pakai mu sifat henji

(don't have this kind of character)

Ya bani mak ngehaqti

(rude and rebellious)

Pedom ya sihena ni

(sleep always comes first)

Minjak ia sihuqi ni

(wake up always late)

Tiguqah ngison hani

(if you wake up always say lazy, still cold)

Kemuliaan mu jak Penanggungan

(your girl from Penanggungan Village)

Judu meqanai jak Gedung Nyawa

(matched with boy from Gedung Nyawa Village)

Ammon Niku Manjau Kuaqian

(if you come to the place of your biological parents)

Dang lamon ga ceqita

(don't tell too much about your husband's family)

Score

Value is a quality of something that makes it likeable, desirable, pursued, valued, useful, and can make people who understand it become dignified.

The value analysis in this study is limited to cultural values and religious values. This is because these two values are prominent in the oral literature of Tembang Pisaan. [10] Religious values are values related to the relationship between man and God, human relationship with society, and human relationship with himself.

The relationship between humans and God is in the following values:

Human nature who is always grateful to God Almighty and human nature who always brings himself closer to Allah SWT by praying for people, especially families who have passed away. This is found in the first, second, third, and eighth lines of the following pisaan song.

Sedekah sa ktaqwa pesolko sapi

(in this party you got slaughtered some cows)

Tandoni syukur di si kuasa

(as a sign of gratitude to Allah SWT)

Teqimakasih di anak muaqi

(thanks to the whole big family) 
Gusi pehun kok pandai tengan

(you guys are ready to end this event)

Nak Umar mangku marga

(Mr. Umar Mangku Marga)

Gelaqni akasmu bijo kaqwa

(that's the name of your grandfather)

Tehna tutukanni agama

(he is a religious figure)

Galak-galak kiqimi fateha

(Pray for him often)

The cultural context behind the pisaan song is the customs of the Daya community of Runjung Agung Subdistrict, which prioritizes the use of the pisaan song as a regional oral literature which is usually used as a complement to the ceremony of giving the customary title, namely adok as a customary title for the groom and iny as a title for the bride. as well as the implementation of the sabay dance, which is a dance that is followed by the extended family of the two brides whose aim is to familiarize both parties.

Tembang pisaan is carried out in traditional events at wedding ceremonies. The customary title is only given to a man and woman who are already tied to a marriage. The awarding of this customary title is also accompanied by the offering of the pisaan song and is marked by the embedding of a keris to the groom as a sign that a man is no longer a virgin, but has the status of the head of the household, who must be responsible and be able to protect his family and use The scarf to the bride means that a woman who is tied to a marriage rope must be responsible for taking care of her husband and children.

The customary title given is in accordance with the order and social status of the groom's family. The customary title given must be accountable for in the community, in everyday life those who have received a customary title will not be called by the birth name from birth, but will be called by the name of the customary title given. Therefore, customary titles are also called second names. Hence the cultural context in oral literature Tembang pisaan contains customs, moral messages, and cultural treasures which are very useful for the community who enjoy literature and support literature.

\section{Tembang Pisaan}

Tembang pisaan is a traditional poem of the Regional Daya District of Runjung Agung which is commonly used as an introduction to traditional events, a complement to the release of the bride to the groom's place, a complement to traditional dance events (sambay dance), as a complement to giving traditional titles (adok and iny). Tembang pisaan contains moral messages, expressions of feelings, advice, and is also rich in cultural values and local customs. This pisaan song is an oral literature in the Daya area of the Runjung Agung subdistrict which is threatened with extinction, because only old people or traditional leaders, only village elders know about the pisaan song.

\section{Conclusions}

The oral literature of the Tembang Pisaan is understood as a medium in giving traditional titles as well as a complement to the Sabay dance. This pisaan song is sung in a seductive way.

\section{References}

La, Ode Nggawu. 2011. Speech at the Tungguno Karete Defenagho Stage in the Marriage of the Muna Community in Kendari. Kendari: South Sulawesi Provincial Language Office.

Andrimar. 2017. "Oral Literature of Koba Panglimo Awang of the Pangaraian Sand Malay Community". Indonesian education university. http: // repository. Upi. Edu.

Marwati and Anton. 2015. "Traditional Expressions in the Traditional Marriage Ceremony of the Bajo Community in Balu Island, West Muna Regency". Humanika Journal No. 15, Vol. 3. December 2015 / ISSN 1979-8296. http: // els. Uho. Air conditioning. Id.

Muliawan. 2014. Educational Research Methodology. Yogyakarta: Gava Media. 
Agustine, Ine. 2010. Encyclopedia of Literature. Bandung: Kreasindo

Rokhmansyah, Alfian. 2014. Theory and Literature Assessment. Yogyakarta: Graha Science.

Jabrohim. 2012. Literary Research Theory. Yogyakarta: Student Library.

Dibia, Ketut. 2018. Appreciation of Indonesian Language and Literature. Rajawali Pers. Depok.

Cemerlang Literature Team. 2018. Complete Indonesian Literature. Bandung: Brilliant. $\backslash$

Peni Puspitasari. 2020. "Research on Story Structure, Context, Co-Text, Inheritance Process, Functions, Values, and Design of the Revitalization Model of the East Java Jemblung Oral Tradition." ISSN 1412565 X. http: // ejurnal. Up. Edu. 